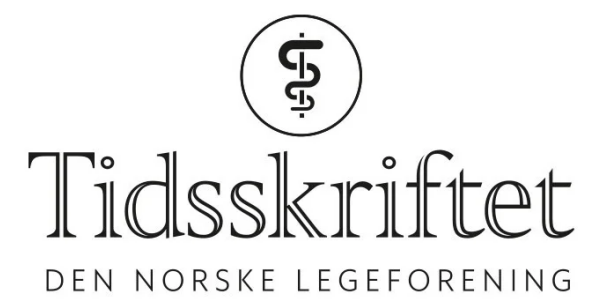

\title{
Olsvik og organismene
}

INTERVJU

MARTIN HOTVEDT

martin@hotvedt.no

Universitetssykehuset Nord-Norge

Han fikk nesten skåret opp halsen da han ble rammet av et luftveisvirus som syvåring. 6o år senere har professor og mikrobiolog Ørjan Olsvik reist verden rundt for å bekjempe mikroorganismer. Nå jobber han døgnet rundt mot koronaviruset. 


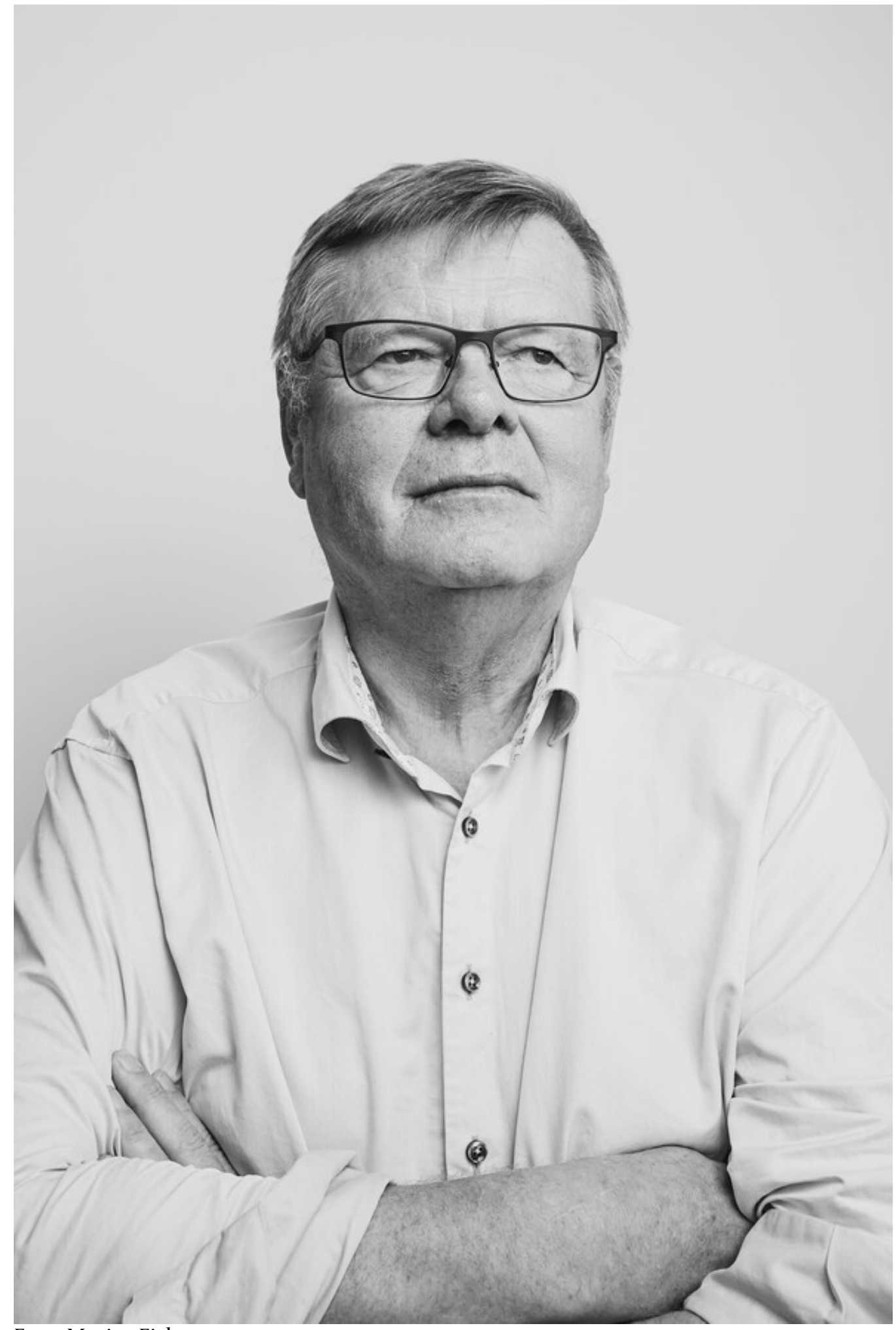

Foto: Marius Fiskum

Mikrobiolog Ørjan Olsvik sitter hjemme i sofaen og prøver å svare på om han har hatt noen skikkelige infeksjoner i sitt 66 år gamle liv.

- Det satt ei dame ved sykesenga som var klar til å skjære opp halsen min med en skalpell. Jeg var innlagt med falsk krupp som syvåring. Sykepleieren var klar til å ordne frie luftveier hvis jeg ble for tett. Jeg lå i et damptelt og husker at hun satt der med skalpellen $\mathrm{i}$ beredskap, svarer han.

Viruseksperten, som selv ble rammet kraftig av et luftveisvirus som barn, er en svært ettertraktet mann om dagen.

Koronavirusets ferd over verden har satt også Norge i unntakstilstand. 
Olsvik, med sin verdensomspennende erfaring fra alvorlige utbrudd av hiv, ebola, kolera, zika, sars og mers, blir daglig spurt om å gi en kommentar og komme med et innspill.

- Hver dag er det intervjuer med media, møter med ei forskningsgruppe i Oslo, telefoner til mine kolleger i USA, opptil ti kontakter med flinke folk i Helsedirektoratet, ramser han kjapt opp.

- Jeg forsøker bare å formidle det jeg vet via mine kanaler og min erfaring, så får lederne ta beslutningene.

Han har blitt en viktig bakmann i kampen mot koronaviruset.

Mens de første ukene av koronapandemien gikk med til å gi råd om smittevern og isolasjons- og karanteneprinsipper til myndighetene, har han nå rettet blikket fremover, mot spørsmålene alle ønsker svar på: Når kan Norge slippe opp restriksjonene? Når kan samfunnet returnere til normalen? Når er vi kvitt korona?

Olsvik har et lite forbehold først.

- Å uttale seg sikkert om fremtiden skal man være forsiktig med.

Han legger armene i kors, og fortsetter, rett på sak:

-Vi må slippe opp nå etter påske. Vi må gjøre det sakte og kontrollert, og vi må verne om risikogruppene i lang tid fremover, sier han og fortsetter:

- Men korona må vi igjennom, og vi må ha en viss sirkulasjon av viruset for å bli immune, sier han, og leverer noen raske fakta i kjent Olsvik-stil:

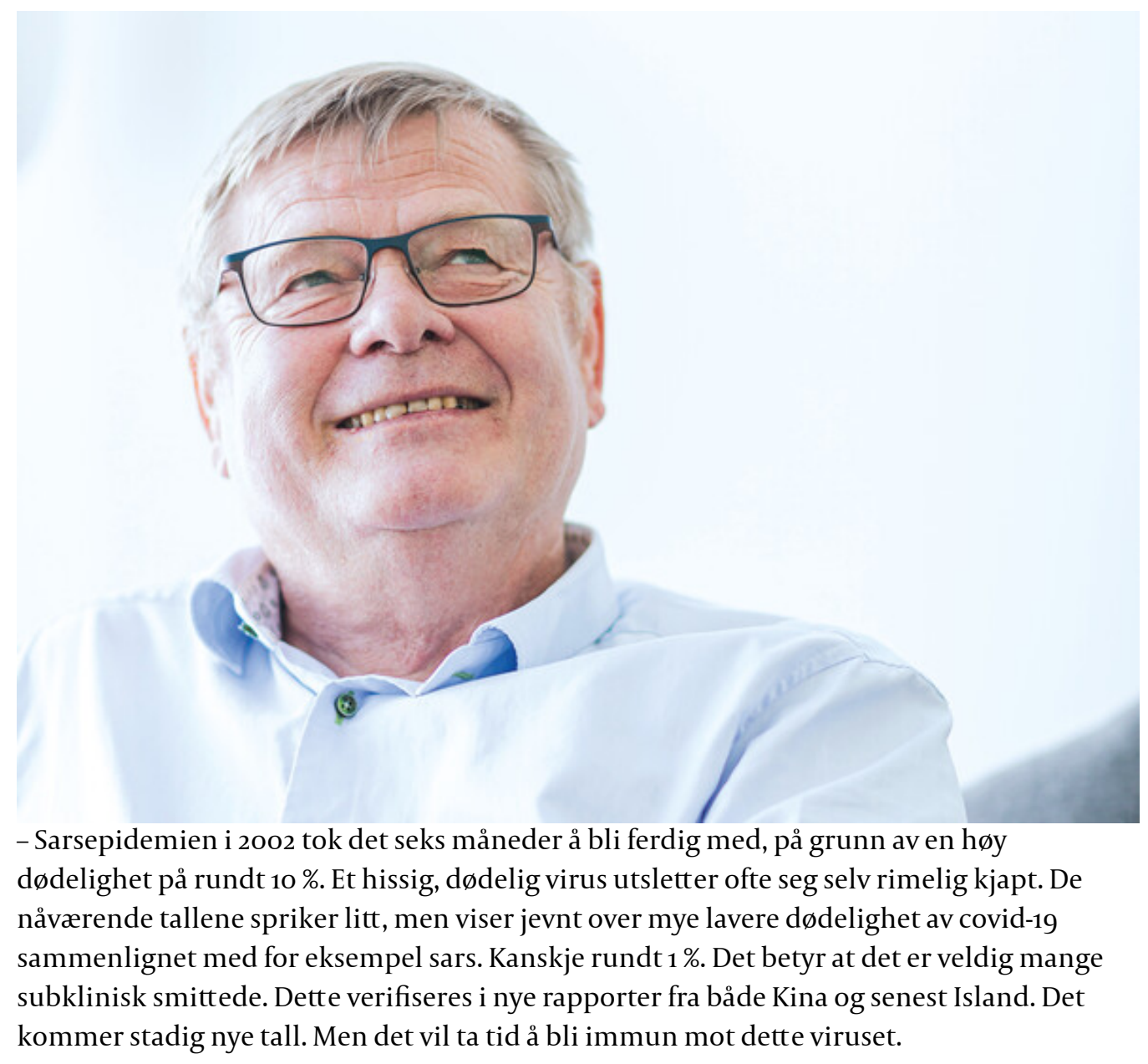

«Barna er ikke $i$ den fremste risikogruppen, vil nok vere rimelig enkle å dressere $i$ håndhygiene og har foreldre som vi trenger $i$ arbeidslivet» 
Han puster kort inn og fortsetter:

- Norge kan ikke stenges ned så mye lenger. Det koster oss over en milliard om dagen. Det er et ubehagelig tema, men vi må begynne å regne nøye på dette nå, sier Olsvik.

I disse dager ferdigstiller han forskning på kostnad og nytte av nedstengning av samfunnet i epidemier, i samarbeid med forskere fra blant annet Princeton University i USA.

- Det høres litt ut som taktikken til den omstridte svenske statsepidemiologen Anders Tegnell?

- Det kan du si, de ønsker jo også en viss sirkulasjon av viruset for å opparbeide immunitet hos folk samtidig som økonomien ikke skal kveles. Men de feilet kanskje litt på det viktigste - å unngå smitte i sykehjemmene og hos de eldre. Det er jo de virkelige risikogruppene.

Olsvik legger til at han tror barnehageoppstart etter påske er lurt.

- Barna er ikke i den fremste risikogruppen, vil nok være rimelig enkle å dressere i håndhygiene og har foreldre som vi trenger i arbeidslivet, sier han kontant.

Et langt liv i Forsvaret har lært ham «å snakke mellom to punktum», som han selv forklarer det.

- Fagfolk må være tydelige, droppe innskutte bisetninger og sånn. Vi må dele og bidra til at kunnskapsreservoaret som universitetene har bygd opp - med skattebetalernes penger spres til alle typer folk.

Øynene til Olsvik spretter iltert opp når han får fortelle om hvordan flaggermusen kan bære på over 6o virus, om utspekulerte sandfluer i Afghanistan og om hvordan vannskrekken slår inn hos et menneske som har blitt smittet av rabies.

Han synes det er viktig å svare når folk spør.

Og folk spør!

- Det er alt fra aksjemeglere til katteeiere som ringer meg. Jeg forsøker å svare alle. Men prøver ikke å være spåmann.

Han smiler og kikker ned på mobilen som kvitrer jevnt i kor med kjøttmeisen utenfor. 35 uleste e-poster og 10 ubesvarte tekstmeldinger hittil i dag.

\section{Fikk jobb ved en tilfeldighet}

- Livets tilfeldigheter.

Det er det han svarer når han blir spurt om hvordan han har kommet seg i denne posisjonen.

For hvordan klarte den bittelille gutten i en bitteliten klasse i en bitteliten bygd på Senja å bli rådgiver for Verdens helseorganisasjon, Verdensbanken, Helsedirektoratet, Forsvaret og jobbe 12 år i det amerikanske folkehelseinstituttet Centers for Disease Control and Prevention?

\section{Ørjan Olsvik}

Født 1953 i Risøyhamn

Forsker, Centers for Disease Control and Prevention 1983-95

Ph.d., Det medisinske fakultet, Universitetet i Oslo 1989

Professor II i genteknologi og mikrobiologi, Veterinærhøgskolen 1990

Professor i medisinsk mikrobiologi, Universitetet i Troms $\emptyset 1994$ 
Redaksjonsmedlem, Journal of Clinical Microbiology

Diverse utmerkelser (Fulbright Award, Fogarty Award osv.)

Fellow, American Academy of Microbiology og Infectious Diseases Society of America Konsulent, Forsvaret som spesialist i utbrudd, bioterrorisme og biologiske våpen

Var det senjaværingens avslappede holdning til livet?

- «Olsvik, jeg vet da faen hva det er du har. Neppe intelligens. Kanskje kreativ faenskap!»

Sitatet er fra en av de mange lærerne han drev til vanvidd i studietiden.

Kanskje ikke en helt fjern slutning, da unge Olsvik hadde koblet om alle leddene til anatomiskjelettet, og litt senere kokte alle eggene som egentlig var tenkt til cellebiologiundervisninga.

- Man trenger aldri å bli helt voksen selv om man jobber med seriøse ting, smiler han lurt.

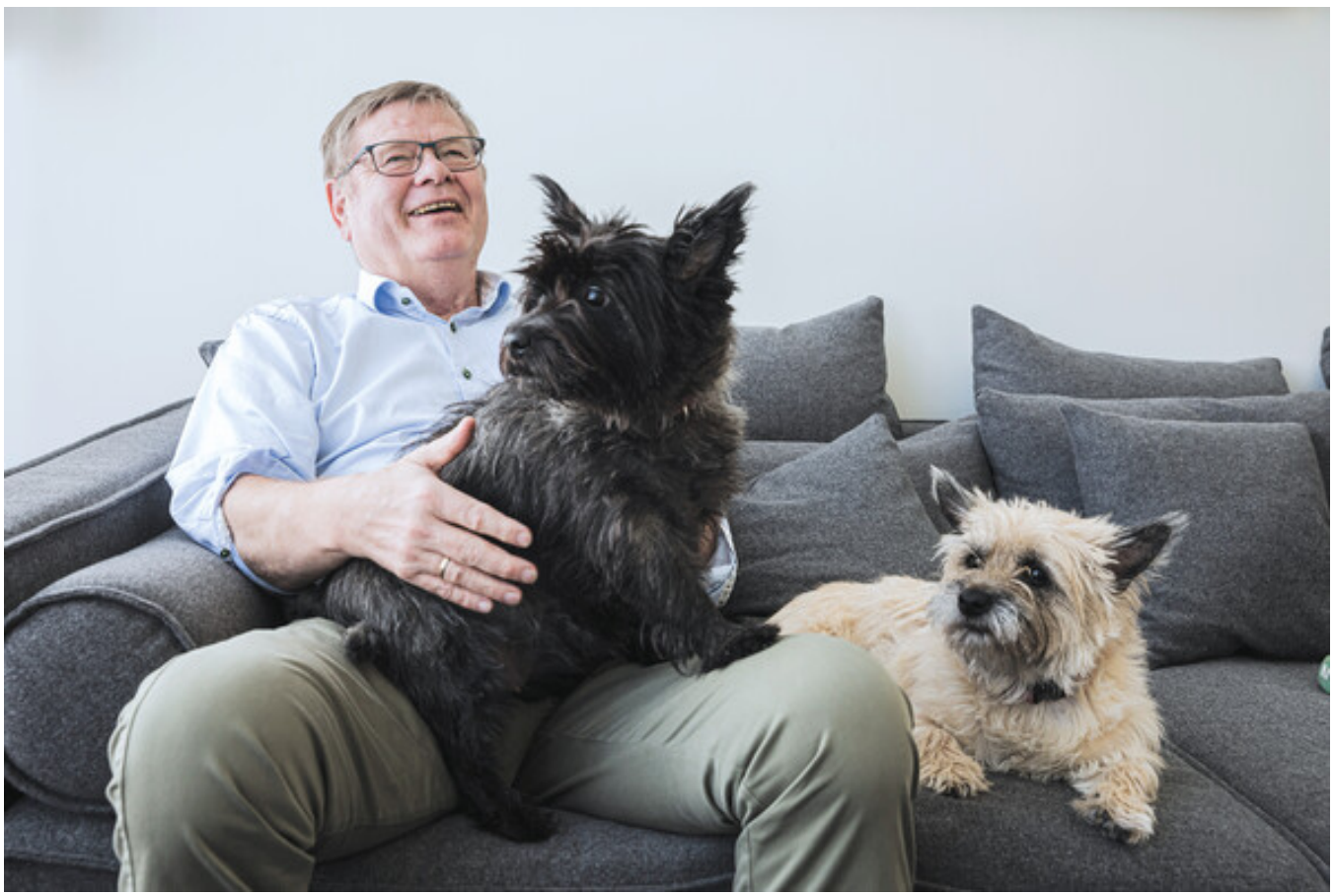

Reisen til et langt liv i mikrobiologiens verden startet dagen etter at Olsvik var ferdig på gymnaset. Han ble kjørt av foreldrene sine til Tromsø for å finne seg jobb.

- Far var rådmann i kommunen og opptatt av å være skikkelig. Mor var husstellslærer. Alt skulle være så skikkelig. Man skulle ha en skikkelig jobb og tjene til livets opphold, sier han, og markerer ordene med fingrene.

- De satte meg av utenfor regionsykehuset og ønsket meg lykke til. Jeg hadde ikke hybel engang.

Heldigvis var vaktmesteren på Mikrobiologisk avdeling for sein på jobb den dagen.

- Takket være en streng overlege ble vaktmesteren oppsagt på stedet, og jeg hadde fått et smutthull inn, ler han.

Siden ble det førstegangstjeneste i Forsvarets mikrobiologiske laboratorium hos den smått legendariske overlege og oberst Tov Omland.

Olsvik forsket seg gjennom verneplikten, utviklet immunologiske hurtigtester som erstattet bruken av mus, rotter og kaniner i diagnostikken av farlige infeksjonssykdommer. 
- Under overlege og senere professor Bjørn P. Berdals ledelse var vi, i all beskjedenhet, helt i den internasjonale forskningsfronten, skyter han stolt inn.

Streng disiplin og høyt arbeidspress passet ham godt.

- Jeg lærte at man møter på jobb klokken o8:oo:oo. Ikke kast bort andres tid! Det er fortsatt mitt motto. Det gleder meg for eksempel at dere i Tidsskriftet var presis i dag. 12:0o:oo. Perfekt.

Han blinker.

Olsvik imponerte og steg i gradene.

- Før jeg visste ordet av det hadde obersten ordnet stilling for meg som amanuensis hos professor og senere rektor Kåre Fossum ved Veterinærhøgskolen, og i neste øyeblikk satt jeg på et fly til Kenya for å undervise i folkehelse.

Han smiler, prater fort, rister på hodet.

- Jeg kunne jo ikke stave Kenya en gang. Trodde man skrev K-e-n-j-a!

- Du er eventyrlysten?

- Det var vanskelig å si nei. Det var et privilegium å få reise verden rundt og møte andre kulturer. De lot meg pendle Norge-Kenya i store jumbojeter fordi jeg var nygift. For en som elsker fly, var jo det et fantastisk opplegg, sier han, og peker på en Concorde-flymodell i stua.

Gjennom amerikanske kontakter fikk han tilbud om å søke forskningsstipend og arbeidsopphold ved det respekterte Centers for Disease Control and Prevention i USA.

- Med forbehold om at jeg passerte inntakskravene, må vite, sier han.

- Tøffe krav?

- For noen. Det gikk mest på stressmestring og samtaler. Og så var det noen sånne IQ-tester med figurer opp-ned-bak-fram.

Han smiler, og fortsetter.

- Og så tror jeg at de så på meg som en ærlig kar. Jeg hadde ingen agenda. Da de andre forskerne fra Stanford og Yale svarte at de bare skulle forske enda mer på fritiden, tror jeg komitéen ble lei. De svarte jo ikke på spørsmålet!

Rypejeger Olsvik svarte akkurat det han hadde tenkt til.

- Kanskje finne meg noen nye våpen til jakta og invitere til grillfest!

Våpensamleren i komitéen ansatte Olsvik på flekken, og familien flyttet til Atlanta.

\section{Jorda rundt fra USA}

Centers for Disease Control and Prevention sendte ham ut på oppdrag til alle verdens kontinenter: jakten på «pasient null» i hivepidemien, kolerautbrudd i USA, diaréforskning i Bangladesh.

Han har livstidsgullkort hos SAS.

«Man trenger aldri å bli helt voksen selv om man jobber med seriøse ting» 
- På kontoret mitt har jeg vinmenyen fra min eneste flight med Concorde, som jeg kikker på hvis jeg har en dårlig dag.

- Selv om jeg og min daværende kone Bente hadde mistet en datter i krybbedød og hadde hatt det tøft, ble det en fin periode etter hvert. Vi fikk to flotte gutter, og i en periode pendlet (!) jeg fra USA til Bangladesh.

Olsvik bodde i et flott hus med syv tjenere og to sjåfører.

Ting så bra ut for den fremadstormende forskeren.

\section{Mistet kona i kreftsykdom}

Og så snudde alt.

- Da Bente kom på besøk og jeg skulle vise frem dette flotte stedet, nevnte hun en kul i brystet. Liten. Men det var tatt noen prøver, og vi lot det være for en stund.

Han kikker ned på stuegulvet.

- Ondartet, sier han. - Og med spredning til lymfesystemet.

Amerikanske myndigheter sto på hodet for familien Olsvik og styrte behandlingen med toppet lag. En kirurg ble fløyet inn i helikopter.

- Men det gikk ikke. Da vi skjønte at dette gikk mot slutten, ville vi hjem. Nordover. Til Troms $\emptyset$, familien og universitetet.

Olsvik måtte finne mening i det meningsløse og lete etter lys da det var som mørkest, som han selv har sagt.

- Den dagen Bente døde, tok jeg guttene til meg og sa: Nå har den dagen vi har gruet oss til, kommet. Nå slipper vi å grue oss mer. Men vi har en jobb å gjøre. En jobb som mamma ville vært stolt av.

Han pauser.

- Jeg har aldri vært typen som legger meg ned og gir opp. Hendelsen lærte meg å ta vare på de rundt meg som har det tøft, enten det er uflaks eller selvforskyldt.

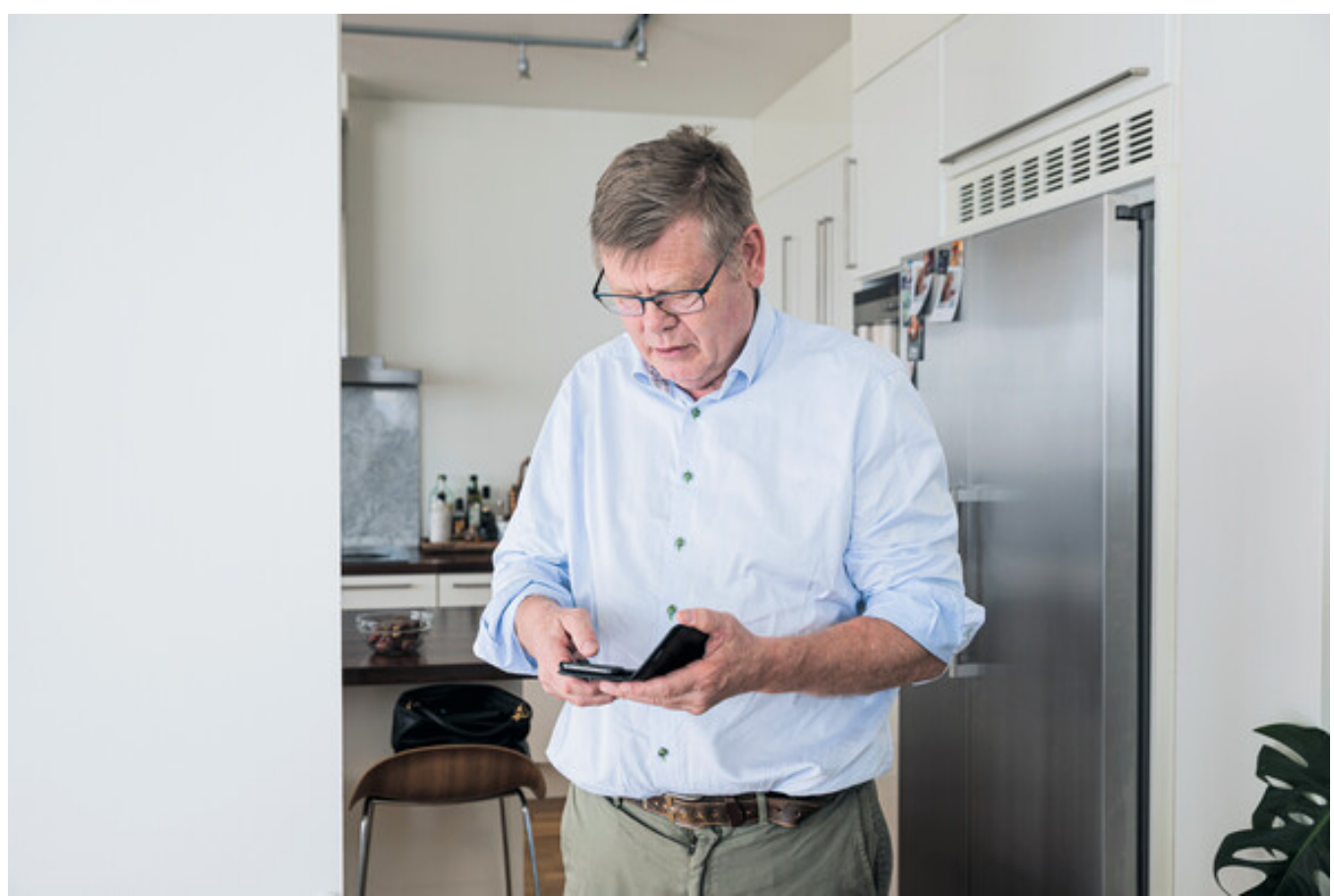

Jeg har jo kompiser som har gjort veldig dumme ting, og da prøver jeg å si at «du e en hestpeis, men du e no våres hestpeis».

Han tar en tenkepause. 
- Man kan ikke glede seg over sola uten å ha vært i skyggen. Og har man unger, kan man i hvert fall ikke sette seg ned og lage hus og heim til et mausoleum, et sorgens hus. Livet skal jo leves videre på en eller annen måte.

- Du var på jobb allerede morgenen etter at din kone gikk bort?

-Klokken o8:oo. To timers forelesning.

- Jøss.

- Jeg sa til studentene at dette kommer til å bli forlangt av dere i helsevesenet. Å ha det slitsomt, men kunne gjøre den viktige innsatsen. Det er jo litt militært, jeg ser den.

Siden tok han med seg guttene sine på reiser og oppdrag rundt om i verden. De har spilt gatefotball i Afrika og hørt på forelesninger om seksuelt overførbare sykdommer i USA i kanskje litt for ung alder.

Et forsiktig smil drister seg fram.

I dag har han vært lykkelig gift med Nina i 19 år.

\section{Advarer mot frykt}

Dette intervjuet gjøres i april, med påsken rett rundt hjørnet. Tromsø-solen har på sitt forsiktige vis satt i gang snøsmeltingen, og Norge står stille. Fortsatt. Det ble ingen påskeferie på den elskede hytta i Aglapsvika, tre timer fra Tromsø.

- Det er to ting du ikke vet hva er før du mister det, sa min sjef Tov Omland. Det er helse, og det er frihet. Jeg tror mange har følt på det i det siste.

- I februar publiserte du kronikken Frykt ikke korona hos NRK og fikk kritikk. Står du fortsatt for den?

- Hovedpoenget mitt var at vi kommer ingen vei med frykt. Jeg har sett hvor invalidiserende det kan være. Man følger frykten, lar seg styre av den og tenker ikke rasjonelt. Dette er et kjent problem hos soldater.

Olsvik har i mange år vært en del av Forsvarets Rapidly Deployable Outbreak Investigation Team, et lite team av eksperter fra det sivile samfunn som er tilknyttet Forsvaret for å bistå når det er alvorlige infeksjonsutbrudd der norske soldater befinner seg.

\section{«Samfunnet faller tilbake til normalen. Det har det alltid gjort etter slike} utbrudd»

I 2014 ble han sendt til krigen i Mali, kanskje det farligste FN-oppdraget i verden, for å bistå forsvaret og sitte i presidentens ebolautvalg.

- En av tingene vi jobbet med var frykt. Jo visst kan ebola føre til at du blør ut fra alle kroppsåpninger, men man må forsøke å holde seg rasjonell og følge de offentlige rådene. Det var det jeg prøvde på i kronikken min også.

- Tror du koronapandemien forandrer oss?

- Nei. Samfunnet faller tilbake til normalen. Det har det alltid gjort etter slike utbrudd. Verden har vært utsatt for verre ting enn dette. Men som sagt tror jeg det kommer til å dra ut.

- Hva tror du vi kommer til å slite med i fremtiden?

Han myser ut i rommet. Tenker fort.

- Antibiotikaresistens blir et vanvittig problem. Tropesykdommer kommer til å øke på grunn av reising og global oppvarming. Før var det kult å ha vært på Gran Canaria, men nå skal man jo helst ha kjørt opp Mekongdeltaet i bar overkropp i en båt for å imponere. Da 
kan du få med deg noen «godiser» hjem.

- Hva med biologisk krigføring?

Han rister febrilsk på hodet.

- Tvilsomt. Det er ekstremt lite effektiv krigføring, for det kan ramme avsenderen, og man kan vaksineres mot det meste etter hvert. Men du verden hvor redd du kan få folk av det!

Han skyter inn en siste anekdote:

- Du vet anthrax-sporene som ble sendt rundt i konvolutter etter 11. september-terroren, de kan man egentlig ikke se. Men det hvite pulveret, det var skummelt!

Han smiler.

- Hvis jeg får tid en dag, blir det kanskje noen bøker av dette. Historiske tilbakeblikk på hvordan samfunnet takler utbrudd. Kanskje litt om koronaen, også.

Han kikker med ett øye ned på mobiltelefonen.

«Hei, jeg er en journalist som skal lage en litt gøyal koronaquiz ...»

Han sukker.

- Det blir en del. Det gjør det.

- Men du liker at det er litt action i mikrobiologiens verden?

- Det er alltid action i mikrobiologiens verden. Dere ser det bare ikke!

Publisert: 24. april 2020. Tidsskr Nor Legeforen. DOI: 10.4045/tidsskr.20.0319

(C) Tidsskrift for Den norske legeforening 2023. Lastet ned fra tidsskriftet.no 26. april 2023. 